\title{
PEREMPUAN DALAM NOVEL BUMI MANUSIA KARYA PRAMOEDYA ANANTA TOER
}

\author{
Ahsani Taqwiem \\ Fakultas Keguruan dan Ilmu Pendidikan, Program Studi Pendidikan Bahasa Indonesia \\ Universitas Lambung Mangkurat \\ ahsanitaqwiem@ulm.ac.id
}

\begin{abstract}
This study aimed to describe the picture of feminist ideology in the novel Bumi Manusia. This research is a qualitative research with descriptive method that uses words as data source. Sources of research data is derived from the text of the novel Bumi Manusia written by Pramoedya Ananta Toer. Instrument research is the researcher himself because the researcher as data collector and also as data analyzer. Based on the results it is found that Bumi Manusia is a novel that contains the ideology of colonial feminism with the aim of reconstructing the position of women in society.
\end{abstract}

Keywords: feminist, novel, women, Pramoedya Ananta Toer

\begin{abstract}
ABSTRAK
Penelitian ini bertujuan untuk mendeskripsikan gambaran ideologi feminis di dalam novel Bumi Manusia. Penelitian ini merupakan jenis penelitian kualitatif dengan metode deskriptif yang menggunakan kata-kata sebagai sumber data. Sumber data penelitian ini berasal dari teks novel Bumi Manusia karya Penulis Ananta Toer. Instrument penelitian adalah peneliti sendiri karena peneliti sebagai alat pengumpul data sekaligus menjadi penganalisis data. Berdasarkan hasil analisis Bumi Manusia merupakan sebuah novel yang mengandung ideologi feminisme poskolonial dengan tujuan merekonstuksi posisi perempuan di dalam masyarakat.
\end{abstract}

Kata kunci : feminis, novel, perempuan, Pramoedya Ananta Toer

\section{PENDAHULUAN}

Sastra bukanlah sesuatu yang kosong. Ia adalah produk kebudayaan dari zaman yang membidaninya. Karya sastra bersifat representatif sebab dunia di dalam karya sastra dapat digunakan sebagai salah satu cara melihat keadaan masyarakat di mana karya sastra itu lahir dan tumbuh.

Sebuah karya dapat digunakan untuk melihat bagaimana posisi perempuan di dalam masyarakat. Kajian yang melihat sesuatu dari sudut pandang perempuan dan bertujuan untuk menunjukkan adanya ketidaksetaraan perlakuan terhadap perempuan dan pria adalah salah satu fungsi kajian feminis. Annette Kolodny (dalam Djajanegara 2000) mendefinisikan kritik sastra feminis sebagai upaya membeberkan perempuan menurut stereotipe seksual, baik dalam kesusastraan maupun dalam kritik sastra, dan juga menunjukkan bahwa aliran-aliran serta cara-cara yang tidak memadai telah digunakan untuk mengkaji tulisan perempuan secara tidak adil dan tidak peka.

Bumi Manusia menjadi novel yang penting karena mampu menggambarkan suasana masyarakat yang akhirnya menjadi cikal bakal pergerakan nasional menyongsong kemerdekaan. Berdasarkan hasil pembacaan dapat kita ketahui novel ini berlatar awal abad-20. Tahun-tahun tersebut terjadi pergolakan pemikiran mengenai keadaan masyarakat dan keadaan terjajah yang pada Bumi Manusia 
terwakilkan oleh Minke sebagai tokoh utama.

Melalui uraian yang telah dipaparkan di atas bahwa penelitian ini akan mengkaji teks Novel Bumi Manusia karya Penulis Ananta Toer dengan memperhatikan segi-segi feminisme yang digunakan untuk menemukan bagaimana gambaran budaya patriarki yang merugikan perempuan serta gambaran ideologi feminis yang terkandung di dalamnya. (Djajanegara, 2000)

\section{KAJIAN PUSTAKA}

Ideologi sebagai sebuah sekumpulan ide dan gagasan banyak mempengaruhi aspek-aspek dalam kehidupan. Banyak definisi mengenai ideologi. Definisi yang netral mengatakan ideologi adalah sebuah cara berpikir untuk mengatur bagaimana masyarakat seharusnya dan cara memperbaikinya. (Adams, 2004)

Secara etimologis, feminisme berasal dari kata Femme (woman), perempuan (tunggal) yang bertujuan untuk memperjuangkan hak-hak kaum perempuan (jamak) sebagai kelas sosial. Feminisme adalah paham perempuan yang berupaya memperjuangkan hak-haknya sebagai kelas sosial. Adapun dalam hubungan ini perlu dibedakan antara male dan female (sebagai aspek perbedaan biologis dan hakikat alamiah), masculine dan feminine (sebagai aspek perbedaan psikologis dan cultural). Sementara itu,masculine-feminine mengacu kepada jenis kelamin atau gender sehingga he dan she. (Selden dalam Sugihastuti, 2000)

Feminisme mengusahakan perwujudan sebuah masyarakat ideal dengan perempuan sebagai salah satu aspek di dalamnya. Hal tersebut dapat ditelusuri baik oleh para penulis perempuan maupun para penulis laki-laki yang peduli akan nasib perempuan. Memahami ideologi sebagai sebuah dasar pemikiran dapat membantu penelitian ini menemukan gambaran-gambaran mengenai perempuan di dalam novel Bumi Manusia.

\section{METODE PENELITIAN}

Metode adalah cara yang digunakan untuk mencapai tujuan penelitian atau mencapai pokok permasalahan. Penelitian ini termasuk jenis penelitian kualitatif dengan menggunakan deksirpsi sebagai pendekatan. Bogdan dan Taylor (dalam Moleong, 2000) mendefinisikan metodologi kualitatif sebagai prosedur penelitian yang menghasilkan data deskriptif berupa kata-kata tertulis atau lisan dari orang-orang dan perilaku yang dapat diamati. Menurut mereka, pendekatan ini diarahkan pada latar dan individu tersebut secara holistik (utuh). Kualitatif deskriptif menggunakan data yang tidak berupa angka atau koefisien tentang hubungan variabel (Aminuddin, 1990). Berkaitan dengan penelitian ini, data yang dikumpulkan berupa kutipan kata, kalimat, dan wacana dari novel Bumi Manusia.

\section{PEMBAHASAN}

Banyak aliran feminisme yang berkembang saat ini, namun semuanya bertujuan pada satu pemikiran bahwa bagaimanapun perempuan adalah makhluk rasional, karena itu ia berhak mendapatkan hak, menentukan diri sendiri yang sama sebagaimana laki-laki. (Adams, 2004)

Novel Bumi Manusia dapat dikategorikan ke dalam novel dengan gambaran aliran ideologi feminis poskolonial. Aliran ini berdasar pada pemikiran bahwa pengalaman perempuan di negara dunia ketiga atau di negara bekas jajahan berbeda dengan pengalaman perempuan di negara bagian pertama. Bumi Manusia mengambil latar awal abad ke-20 tepatnya sekitar tahun 1898 saat Indonesia masih menjadi daerah jajahan Belanda dengan nama Hindia Belanda. Ideologi feminis poskolonial coba ditelusuri dari kutiapan kata, tindakan serta pemikiran tokoh utama kepada dirinya serta kepada tokoh lain.

Feminisme poskolonial berpandangan bahwa perempuan di dunia 
ketiga menanggung beban penindasan lebih berat karena selain mengalami penindasan berbasis gender, mereka juga mengalami penindasan antar bangsa, suku, ras, dan agama. Fokus utama dari aliran ini adalah menggambarkan bagaimana penjajahan turut berperan dalam ketertindasan kaum perempuan. Penjajahan yang terjadi baik fisik, pengetahuan, nilai-nilai, cara pandang, maupun mentalitas masyarakat menjadi perhatian dari aliran feminisme poskolonial.

Tokoh-tokoh Bumi Manusia digambarkan sebagai seorang tokoh yang kritis dan peduli terhadap nasib kaum perempuan. Semangat feminis tidak hanya bisa disematkan kepada tokoh perempuan, tetapi juga kepada tokoh laki-laki.

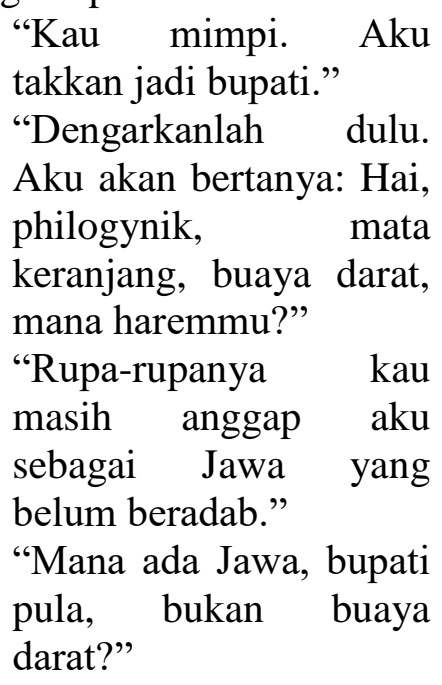

(Toer, 2009: 23)

Persoalan seksual menjadi latar belakang bagi banyak struktur pemikiran yang mencirikan masa kolonial (Mills, 2009). Hal ini memberikan pemahaman kepada kita bahwa memang kolonialisme meninggalkan dampak negatif dalam aspek seksual terutama kepada perempuan yang lebih banyak menjadi objek penindasan, meskipun dalam beberapa peristiwa baik dalam fakta sejarah atau di dalam beberapa karya sastra ditemukan adanya kekerasan seksual antarlelaki.

Kutipan paragraf di atas adalah percapakan Minke dengan Robert Suurhof. Robert menyebut Minke sebagai mata keranjang, buaya darat, dan menanyakan keberadaan harem kepada Minke. Minke membantah dan melemparkan perkataan yang tersirat mengatakan bahwa hanya orang jawa yang belum beradab yang punya kelakukan seperti itu. Sebab jauh sebelum kolonialisme menginjakkan kakinya, praktek gundik, harem, bahkan pelacuran sudah lebih dulu ada.

Penulis melalui tokohnya memberikan pemikiran feminis bahwa orang-orang yang mata keranjang dan mempunyai perempuan simpanan sebagai orang yang tidak punya norma kesopanan, tidak memiliki adab. Kata $a d a b$ adalah sifat yang menandakan seseorang punya aturan dalam bertindak, tidak sekehendak hati dan semaunya, sesuai dengan nilainilai kemanusiaan. Hal ini sejalan dengan tujuan feminis yang menghendaki penghapusan penindasan dan perbuatan kesewenang-wenangan terhadap perempuan. Minke menyebut mereka yang masih melakukan hal-hal tersebut sebagai manusia jawa yang belum beradab bukan tidak beradab. Hal ini menandakan bahwa kenyataan pahit ini bisa diubah dengan memberikan pengertian bahwa perempuan juga manusia yang mempunyai hak-hak hidup sama seperti kaum laki-laki.

Seorang pelayan wanita menghidangkan susu coklat dan kue. Dan pelayan itu tidak datang merangkak-rangkak seperti pada majikan pribumi. Malah dia melihat padaku seperti menyatakan keheranan. Tak mungkin yang demikian terjadi pada majikan Pribumi: dia harus menunduk, menunduk terus. Dan alangkah indah kehidupan tanpa merangkak-rangkak di hadapan orang lain.

(Toer, 2009: 35) 
Kutipan di atas diambil pada bagian cerita Minke telah berada di dalam rumah Nyai Ontosoroh. Pada akhir kutipan Minke mengungkapkan perasaannya tentang betapa indah hidup jika tidak harus merendahkan diri di hadapan orang lain. Sesuai konteks di atas pelayan wanita mewakili perempuan-perempuan pekerja pada masa itu.

Bumi Manusia melawan budaya merendahkan perempuan yang di tandakan kepada budaya merangkak seperti dilakukan para pembantu perempuan. Minke terlihat berandai-andai jika semua pekerja rumahan mendapat kebebasan dan tidak harus merangkak seperti yang selama ini dia ketahui. Merangkak adalah simbol rendah, karena subjek yang merangkak harus memposisikan dirinya lebih rendah daripada orang lain. Meskipun secara konteks budaya merangkak adalah budaya dengan tujuan menghormati orang lain, namun bagi individuyang menganut paham Eropa seperti Minke merangkak sudah tidak pantas lagi dilakukan karena semua manusia seharusnya setara.

Kutipan di atas juga menguatkan bahwa ada perbedaan perlakuan perempuan pada negara dunia ketiga dan negara dunia pertama yang dicontohkan dalam ruang lingkup yang kecil. Perlakuan perempuan di negara dunia pertama atau negara yang merdeka dicontohkan oleh keluarga-keluarga Eropa memperlakukan pekerja perempuan mereka secara bebas dan dihormati hakhaknya sebagai manusia. Sedangkan pengalaman perempuan di dunia ketiga direpresentasikan melalui perlakuan terhadap pembantu perempuan pada keluarga-keluarga pribumi. Mereka diposisikan sebagai seorang individu pekerja dengan kaharusan tunduk secara penuh dan menyeluruh.

"Kau heran melihat
perempuan bekerja?
$\mathrm{Aku}$ mengangguk. Ia
menatap aku seakan

hendak membaca keherananku.

(Toer, 2009: 44)

Keheranan Minke di dalam novel berlanjut saat muncul perasaan heran melihat pekerja perempuan yang bekerja pada perusahaan Nyai Ontosoroh. Bekerja adalah tanda untuk kegiatan-kegiatan mencari nafkah dan bertahan hidup. Pada zaman kolonial bekerja adalah milik lakilaki, perempuan tidak berhak serta dirasa kurang pantas untuk bekerja. Hal ini tidak berlaku di dalam novel Bumi Manusia, Penulis memberikan contoh dan kebiasaaan Eropa yang menerima dan membolehkan kaum perempuan mendapatkan haknya untuk bekerja. Tidak ada perbedaan antara laki-laki dan perempuan untuk mendapatkan penghidupan selama perempuan itu sanggup dan tidak melanggar normanorma yang berlaku. Minke seperti seorang feminis yang mengemukakan bagaimana seharusnya masyarakat ideal dibentuk dengan menyediakan tempat bagi perempuan untuk eksis dan berkembang.

Bekerja adalah sebuah pintu untuk mengurangi kesengsaraan perempuan. Faktor ekonomi adalah faktor penting yang membuat posisi perempuan sulit diangkat di dalam masyarakat. Zaman kolonial hanya membatasi perempuan mengurusi urusan dapur, karena itulah untuk mencari uang para perempuan rela menjadi gundik atau Nyai dari para serdadu kolonial. Bahkan perempuan masa itu menjadi gundik bukan atas kehendak sendiri melainkan kehendak orang tua yang menjual anaknya demi uang. Fakta sejarah memperlihatkan bahwa tulisan-tulisan R.A Kartini (18791904) membantu usaha membuka jalan bagi perempuan mendapatkan pendidikan saat mulai dipublikasikan.

Bumi Manusia dalam beberapa bagian berusaha menggambarkan bagaimana keadaan masyarakat ideal meletakkan perempuan sebagai makhluk yang dihormati hak-haknya. Menjadi 
seutuhnya manusia yang hidup dengan hasil keringat sendiri, tidak perlu hanya bertumpu pada nasib dan kemurahan kaum laki-laki.

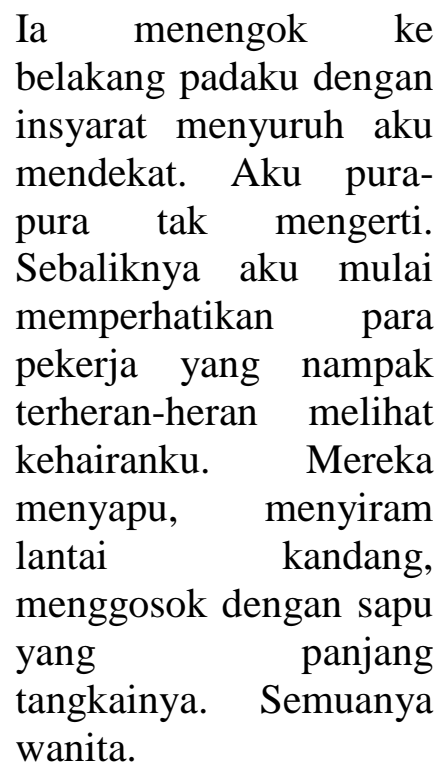

(Toer, 2009: 46)

Akhir kutipan di atas Penulis menegaskan dengan kata-kata semuanya wanita, pekerjaan-pekerjaan laki-laki yang dia sebutkan terdahulu dia tegaskan semua itu disaksikannya dikerjakan oleh perempuan. Penulis menginginkan pembaca menerima kenyataan dan memahami bahwa layat novel pada zaman Minke hidup perempuan bekerja bukan sesuatu yang lazim dan bebas ditemukan.

Minke menjadi stereotipe manusia yang baru mengenal dan memahami bagaimana perempuan harus ditempatkan. Satu bagian dirinya merasa hal ini kurang bisa diterima sisi hidupnya yang jawa dan priyayi, namun sisi lain dirinya yang penuh ilmu pengetahuan serta didikan Eropa membuatnya menerima kemajuan pemahaman yang terjadi dihadapannya.

Mama mempersilakan
aku duduk di
ruangbelakang.
sendiri duduk di
sampingku dan
mengajak aku bicara
tentang perusahaan dan
perdagangan. Ternyata
pengetahuanku
tentangnya tiada arti. Ia

mengenal banyak istilah Eropa yang aku tak tahu. Kadang ia malah menerangkan seperti seorang guru. Dan ia bisa menerangkan! Nyai apa pula di sampingku ini?

(Toer, 2009: 58)

Penulis memberikan semangat kepada setiap orang untuk belajar dan menghormati siapapun yang berkualitas sekalipun menyandang status sebagai seorang perempuan simpanan atau nyai. Bumi Manusia mengingatkan pembaca agar mau belajar pada siapapun karena ilmu tidak dipengaruhi gender dan jenis kelamin. Ilmu adalah bagi mereka yang mau maju dan belajar. Nyai apa pula di sampingku ini menggambarkan betapa Minke terheran menemui seorang Nyai yang notabene seorang yang rendah muncul sebagai individu yang sama sekali berbeda.

Tokoh Nyai di dalam Bumi Manusia adalah sebuah anomali. Banyak novel menempatkan tokoh perempuan adalah sosok yang lemah dan tertindas, namun sosok Nyai Ontosoroh adalah sosok yang sama sekali berbeda dibandingkan misalnya dengan tokoh perempuan di dalam novel Siti Nurbaya karya Marah Rusli. Tokoh wanita pada novel Siti Nurbaya digambarkan tidak relevan untuk mempunyai pendidikan ataupun wawasan yang luas. Tokoh Siti Nurbaya dan Alimah merupakan representasi kondisi wanita yang jauh mengalami ketimpangan dalam emansipasi pendidikan dengan lakilaki pribumi. (Anwar, 2009)

Pendidikan memang menjadi sorotan utama dalam perspektif feminis, apalagi akhir-akhir ini muncul istilah pendidikan feminis dan pedagogis kritis. Novel-novel awal Indonesia yang dimulai sejak tahun 1920-an seperti Azab dan Sengsara (1920) dan Sitti Nurbaya (1922) tidak terlalu mengedepankan masalah pentingnya pendidikan bagi perempuan. Hal ini menjadi maklum sebab karya 
sastra adalah tiruan dari keadaan masyarakatnya. Pendidikan bagi perempuan kala itu sangat minim dan memprihatinkan.

Pendidikan feminis sebenarnya merupakan bagian dari pedagogis kritis. Hal ini karena kedua aliran pemikiran pendidikan tersebut memahami persoalan pendidikan tidak dapat melepaskan diri dari realitas, konteks sosio-kultural yang terjadi dalam masyarakat yang mengandung dikriminasi, ketidakadilan, dan bahkan penindasan. Keduanya memandang pendidikan memiliki peran untuk melakukan pembebasan menuju keadilan dan kesetaraan. (Wiyatmi, 2015)

Perempuan dapat menjadi luar biasa asal ada kemauan belajar serta terus mengembangkan diri. Hal ini sesuai dengan keinginan gerakan feminis agar semua perempuan percaya bahwa dirinya bisa menjadi lebih baik dengan membuka diri dan menerima pengetahuanpengetahuan baru tanpa melupakan kodrat mereka sebagai perempuan. Kutipan di atas mengingatkan agar jangan pernah memandang seseorang dari status sosial dan dari anggapan umum masyarakat sebelum menelaah dan memastikan sendiri. Minke tetiba merasa kerdil pengetahuannya ketika berada di samping perempuan yang awalnya dipandang sebelah mata.

Meskipun meniupkan nafas kesetaraan gender dalam novel yang ditulisnya, namun Penulis tidak melupakan kodrat dari perempuan. Tersirat dari kutipan di atas bahwa bagaimanapun seorang nyai ia tetaplah ibu bagi anak-anak yang dilahirkannya. Bagaimanapun cerdas dan berkualitasnya pengetahuan yang dimilikinya. Laki-laki dan perempuan memang diciptakan berpasangan dan saling melengkapi.

"Dia pembenci Pribumi, kecuali keenakannya, kata Mama. Bagi dia tak ada yang lebih agung daripada jadi orang Eropa dan semua
Pribumi harus tunduk padanya. Mama menolak tunduk. Dia mau mengeasai seluruh perusahaan. Semua orang harus bekerja untuknya, termasuk Mama dan aku."

(Toer, 2009: 97)

Kutipan di atas adalah kutipan saat Annelies menjelaskan kakaknya Robert Mellema kepada Minke. Tersuratkan bagaimana dalam konteks seorang Nyai melawan ketidakadikalan yang ingin menguasai dan menindasnya. Mama menolak tunduk menyuarakan perlawanan yang begitu sarat. Melawan ketidakadilan yang terjadi kepada perempuan adalah salah satu tujuan dari feminisme. Hal ini begitu jelas tergambar pada diri seorang Nyai Ontoroh.

Nyai Ontosoroh melawan kemungkinan-kemungkinan penindasan yang ditujukan kepada dirinya bahkan dari anaknya sendiri, meskipun pada akhirnya dia akan kalah namun kekalahan dengan perlawanan jauh lebih terhormat daripada kekalahan dibarengi kepasrahan.

Mamamu hanya
perempuan Pribumi,
akan tidak mempunyai
suatu hak atas semua,
juga tidak mempunyai
sesuatu hak untuk
anakku sendiri, kau,
Ann

(Toer, 2009: 112)

Perjuangan terhadap hak-hak perempuan memang sangat sulit pada saat Minke hidup, lebih lagi saat itu Indonesia belum merdeka seperti sekarang. Hukum yang berlaku adalah hukum negeri penjajah yang jelas-jelas tidak menghormati mereka yang pribumi. Perempuan pribumi bahkan tidak punya hak terhadap anaknya jika hanya menjadi seorang gundik. Apa yang lebih menyengsarakan selain ibu yang tidak diakui keibuannya. 
Perempuan pribumi menandakan perempuan kebanyakan yang hidup pada masa tersebut. Secerdas apapun, sebaik apapun pengetahuannya, sekali pribumi maka dia harus tunduk terhadap aturan negara jajahan yang berlaku. Mereka melawan hanya saja memang belum punya dukungan dan dasar kuat untuk menang. Hak perempuan yang tertindas coba digambarkan agar perempuanperempuan bisa mengerti dan sadar betapa mereka harus berjuang demi diri mereka sendiri.

Lebih menyedihkan lagi penindasan terhadap hak-hak perempuan tidak hanya dilakukan orang asing, dalam hal ini bangsa penjajah, tetapi juga dilakukan oleh budaya dan orang-orang sendiri.

Ibuku tak punya hak bicara seperti wanita Pribumi seumumnya. Semua ayah yang menentukan.

(Toer, 2009: 119)

Orang tua ikut membenarkan penindasan hak-hak perempuan kepada anak mereka. Hal ini menjadi anggapan umum yang dibenarkan dan diturunkan turun temurun. Perempuan pribumi umumnya terus mengalami penindasan dan tekanan yang menyebabkan mereka dihadapkan pada kenyataan pahit. Hal ini digambarkan sebagai bentuk edukasi agar pembaca mengenal dan menelaah bagaimana seharusnya perempuan diperlakukan dan dihormati hak serta kewajibannya sama seperti kaum laki-laki.

Bumi Manusia menginginkan hakhak perempuan dihormati. Karena itu di dalam novel digambarkan bagaimana keadaan seorang perempuan ketika hakhak tersebut direnggut. Nyai Ontosoroh menganggap dirinya tidak punya orang tua karena dia dijadikan barang dagangan. Dia dijual hanya untuk kepentingan sesaat orang tuanya. Sejak saat itulah muncul dendam dalam hatinya. Tidak akan ada lagi sebutan orang tua bagi ayah ibunya. Dia menunjukkan perlawanan terhadap segala yang menindas hak-haknya. Dia dianggap dianggap warga kelas dua di mata masyarakat.

Kata mempertahankan dalam kutipan di atas menandakan bahwa novel ini mengajak para pembaca agar menumbuhkan semangat perlawanan. Meskipun perlawanan yang dilakukan akan berakhir dengan kekalahan. Para perempuan harus memberikan perlawanan terhadap ketidakadilan yang merongrong hidup mereka. Tanpa melawan tentu hidup dalam kemalangan adalah sebuah kenyataan. Perempuan harus belajar tumbuh mandiri dan tidak perlu sepenuhnya tergantung pada kaum lakilaki.

Segala yang kupelajari
dan kukerjakan dalam
setahun itu telah
mengembalikan
hargadiriku.
sikapku Tetapi
mempersiapkan tetap:
untuk tidak akan lagi
bergantung pada siapa
pun. Tentu saja sangat
berlebihan seorang
perempuan Jawa bicara
tentang hargadiri,
apalagi semuda itu.

(Toer, 2009: 130)

Perempuan harus berjuang mempertahankan harga diri dan tidak bergantung selain pada dirinya sendiri. Melalui Bumi Manusia kita mengetahui bahwa perempuan Jawa dirasa kurang pantas ketika bicara tentang harga diri. Budaya ini terasa janggal sebab memposisikan perempuan sebagai individu tidak beradab dan tidak sopan ketika bicara tentang harga diri. Hal ini menandakan bahwa banyak budayabudaya yang mengekang dan menistakan perempuan tetap dipertahankan.

Sudah saatnya para perempuan mengenali dan memperjuangakan kehormatan dan harga diri. Kalau diri mereka sendiri saja tidak merasa penting membicarakan dan menjaga harga diri 
apalagi orang lain. Harga diri, nama baik, adalah sebuah modal untuk berjalan tegak di atas bumi ini. Dengan memiliki keyakinan dan harga diri yang tinggi maka perempuan akan mampu berjuang dan berusaha hidup di atas usaha dan keringat mereka sendiri.

Nyai Ontosoroh berjuang agar anakanaknya dapat menegakkan kepada di tengah orang-orang yang menghujat. Penulis memberikan gambaran bahwa melawan penindasan dan ketidakadilan terhadap perempuan akan memberikan efek yang panjang dan berkelanjutan. Semua akan berlanjut kepada anak cucu yang akhirnya menjadi pemahaman umum bahwa perempuan adalah makhluk yang harus dihormati sama seperti laki-laki. Sudah sepantasnya seorang ibu menyiapkan jalan agar anaknya tidak merasa sia-sia terlahir ke dunia.

Mungkin saja Annelies
tidak bertepuk, karena
memang tak pernah
memasuki pergaulan
semacam ini. Malah
mungkin ia diam
terlongok-longok di
kursinya-anak tak punya
pergaulan itu-seperti
anak gunung.

(Toer, 2009: 447)

Tergambar bagaimana gambaran seorang perempuan yang tidak pernah bergaul. Bergaul menjadi tanda seseorang ikut bersosialisasi, membuka diri, dan melihat dunia luar. Kejadian di atas terjadi saat Annelies dibawa Minke menghadiri acara pesta kelulusannya sebagai siswa H.B.S. Batavia.

Perempuan harus bergaul, melihat dunia luar, begitulah yang disuarakan novel ini. Dengan melihat dunia luar dan segala sisi-sisinya maka perempuan akan bisa becermin dan menilai dirinya sendiri. Zaman Minke memang perempuan selalu berkaitan dengan urusan dapur dan rumah tangga. Hal ini tidak salah karena memang begitulah kodrat yang harus diterima kaum perempuan, hanya saja hal ini tentu tidak menjadikan perempuan tabu untuk melihat hal-hal menarik di luar tempurung yang mengurung mereka.

Tanpa bergaul perempuan hanya akan jadi seseorang yang terpisah dengan masyarakat. Hal ini terjadi karena tidak pernah tahu ada dunia lain selain dunia yang selama ini dia tekuni. Kalau hal ini terus-menerus dilakukan maka tidak bisa disalahkan penindasan dan ketidakadilan akan terus terjadi.

Bumi Manusia tidak hanya memperjuangkan hak-hak perempuan yang tertindas, di dalamnya kita juga bisa menemukan bagaimana novel ini menguatkan sisi-sisi perempuan yang seringkali dianggap remeh atau bahkan diejek bila dilakukan, padahal hal itu bisa dikatakan kodrat dari perempuan.

Dan setiap yang buruk tak pernah menarik. Perempuan yan tak dapat merawat kecantikan sendiri, kalau aku lelaki, akan kukatakan pada temantemanku: jangan kawini perempuan semacam itu: dia tak bisa apa-apa, merawat kulit sendiri pun tidak kuasa.

(Toer, 2009: 133)

Feminis di dalam novel Bumi Manusia tetap mempertahankan hal-hal yang kondrati seperti bersolek dan merawat tubuh. Penulis novel berharap perempuan dapat maju dan berkembang namun tidak boleh melupakan akar dan asal mereka. Perempuan tetap seseorang yang nanti menjadi seorang ibu, melahirkan, merawat keluarga, dan tentu saja merawat tubuh. Novel ini juga mengingatkan kita bahwa penindasan bisa saja dalam bentuk yang tidak terlihat, karena itulah perlawanan harus dilakukan dengan cermat dan tepat.

"Mevrouw bukan budak, juga tidak seperti budak." 
"Nyai, Juffrouw," Mama membetulkan. "Bisa saja seorang budak hidup di istana kaisar, hanya dia tinggal budak."

(Toer, 2009: 341)

Penulis mengajarkan kita kewaspadaan terhadap penindasan dan perlakuan tidak adil yang terselubung. Budak menjadi tanda mereka yang tertindas dan tidak dihormati hak-haknya. Bukan sesuatu yang luar biasa budak hidup di dalam sebuah kemewahan tetapi sejatinya dia tetap tertindas. Hal ini harus dilawan dan dihancurkan agar tidak ada lagi ketidakadilan atas nama gender.

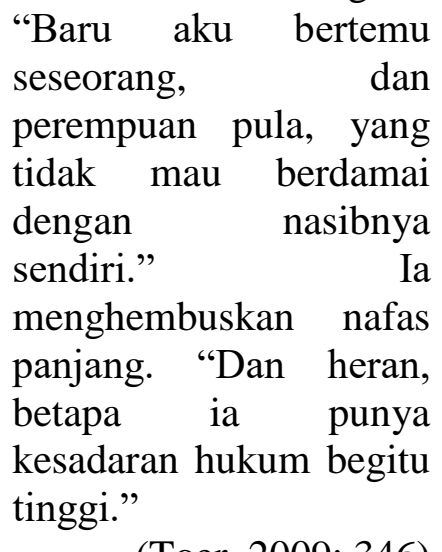

(Toer, 2009: 346)

Setiap perempuan harus punya kesadaran. Kata ini menjadi tanda bahwa setiap perempuan harus mawas diri dan sadar akan hak dan kewajiban dirinya sebagai perempuan. Kutipan di atas adalah ungkapan dari gurunya Minke setelah bertemu dengan Nyai Ontosoroh.

Kesadaran akan akan mendorong setiap perempuan memperjuangkan apa yang menjadi haknya. Kesadaran meliputi banyak aspek hidup yang tentu bisa diketahui kalau kaum perempuan mau belajar, menghargai dirinya sendiri, dan berjuang menggapai itu semua.

Perkataan gurunya Minke, Juffrouw Magda Peters berlanjut dengan pujian terhadap Nyai Ontosoroh.

"Betapa Juffrouw
memuji dia."
"Karena dia Pribumi,
dan wanita, dan memang
mengagumkan....

(Toer, 2009: 348)

Dari kutipan diatas tersurat bahwa tidak banyak perempuan yang seperti Nyai dalam hal keterbukaan dan pengetahuan. Apalagi di zaman Minke yang penuh dengan budaya patriarki yang mengikat.

Novel ini mendorong para perempuan terutama perempuan pribumi untuk mengembangkan dirinya menjadi perempuan-perempaun tangguh dan penuh harga diri. Menjadi wanita mengagumkan tidak bisa dicapai hanya dengan berdiam diri dan menerima nasib. Semua memerlukan pengorbanan yang tidak singkat dan tidak mudah. Perempuan harus berani menantang hidup mereka sendiri agar tidak dipermainkan hidup.

Melawan adalah nafas Bumi Manusia dalam tiap aspek dan bagian novelnya. Koflik yang dialami Nyai Ontosoroh dan Minke juga mereka hadapi dengan perlawanan yang begitu gigih.

"Biarpun tanpa
ahlihukum. Kita akan
jadi Pribumi pertama
yang akan melawan
Pengadilan Putih, Nak,
Nyo, bukankah itu suatu
kehormantan juga?"
(Toer, 2009: 494)

Minke dan Nyai Ontosoroh melakukan perlawanan meskipun bersifat prematur karena tanpa bekal yang cukup dan ideal untuk terus maju. Semangat berusaha dan tidak kenal menyerah inilah yang coba disampaikan oleh novel Bumi Manusia.

Melawan adalah sebuah kehormatan yang tidak semua orang berani mengambil resiko untuk melakukannya. Menghadapi penindasan dan ketidakadilan yang terjadi karena perbedaan gender tidak ada jalan lain selain terus maju menerjang dengan segala daya upaya. Apalagi latar Bumi Manusia saat itu menggambarkan perlawanan perempuan masih bersifat individual dan parsial, perempuan tidak memiliki kelompok atau organisasi yang turut serta membantu memperjuangkan 
hak-hak perempuan. Organisasi semacam Poetri Mardika (1912) dan Isteri Sedar (1930) baru muncul jauh sesudah tahun 1898-an yang menjadi latar novel Bumi Manusia.

Hakikat feminisme adalah perlawanan karena adanya perlakuan yang tidak seimbang terhadap mereka yang lahir sebagai perempuan. Penulis begitu keras dan konsisten meniupkan nafas perlawanan dalam novel Bumi Manusia dalam setiap aspek dan sisi novelnya. Pembaca selalu disuguhi gambaran bagaimana seharusnya seorang perempuan dipandang dan ditempatkan dalam masyarakat. Tujuan semua ini bermuara pada satu impian bahwa akan tercipta sebuah tatanan masyarakat ideal di mana perempuan menjadi salah satu aspek penting di dalamnya, bukan hanya menjadi pelengkap dan warga kelas dua, yang tentu saja tetap selaras dan sesuai dengan kapasitas serta kodratnya sebagai perempua.

Bumi Manusia ditutup dengan manis dan cerdas, di mana Penulis masih saja berdiri dan tetap memegang teguh prinsip bahwa kehormatan manusia terletak pada bagaimana perlawan mereka terhadap ketidakadilan. Melawan dengan segala daya upaya, sehormat dan sebaik-baiknya.

"Kita telah melawan,
Nak, Nyo, sebaik-
baiknya,
hormatnya."

(Toer, 2009: 535)

\section{SIMPULAN}

Bumi Manusia menyuarakan perlawanan oleh kaum perempuan dengan menyandarkan diri pada ideologi feminis poskolonial. Laki-laki dan wanita dicitrakan melalui tokoh-tokoh yang memperjuangkan hak-hak perempuan sebagai manusia.Konflik di dalam Bumi Manusia menunjukkan bahwa perempuan dengan berbagai cara ditekan dan disudutkan, namun tokoh perempuan dicitrakan tidak menyerah begitu saja dalam menghadapi penindasan yang menimpa dirinya karena perbedaan gender. Hal ini juga terjadi pada tokoh laki-laki yang dicitrakan sebagai tokoh yang ikut melawan ketertindasan yang terjadi kepada kaum perempuan.

Bumi Manusia menghadirkan tokoh yang menjadi contoh dalam bersikap menghadapi budaya patriarki yang membelenggu dan membatasi kaum perempuan untuk berkembang mengikuti arus zaman. Bumi Manusia di sisi lain menggambarkan bagaimana seharusnya masyarakat menempatkan perempuan menjadi salah satu bagian penting dan tidak terpisahkan.

Novel di dalam setiap bagianbagian pembentuknya sebagai sebuah karya yang utuh mengandung pesan dan amanat. Tentu untuk menggali pesan dan nilai-nilai tidak bisa dengan pembacaan biasa. Setiap orang tentu harus berusaha menjadi pembaca ideal dengan membaca karya-karya sastra secara kritis. Karena hal itu semua kalangan dalam dunia pendidikan harus meningkatkan minat baca terhadap karya-karya sastra.

Novel memberikan pelajaran dalam hidup yang penting dan sarat. Novel-novel Indonesia harus terus dikaji dan ditelaah dari berbagai macam sudut pandang dengan metode-metode terbaru. Hasilnya tentu akan menjadi bahan koreksi terhadap masyarakat, sistem sosial dan kebudayaan. Selain itu dengan terus dibaca maka novel Indonesia tentu akan mampu menjadi tuan rumah di negeri sendiri. Sebuah bangsa yang bermartabat adalah bangsa yang menghargai setiap karya yang lahir dari dan untuk bangsanya. 


\section{DAFTAR RUJUKAN}

Adams, Ian. (2004). Ideologi Politik Mutakhir. Yogyakarta: Qalam.

Aminuddin. (2004). Pengantar Apresiasi Sastra. Bandung: Sinar Baru Algensindo.

Anwar, Ahyar. (2009). Geneologi Feminis. Jakarta: Republika.

Djajanegara, Soenarti. (2000). Kritik Sastra Feminisme: Sebuah Pengantar. Jakarta: Gramedia.

Mills, Sarra. (2009). "Teori Feminis Poskolonial" dalam Teori-Teori Feminis Kontemporer (ed. Stevi Jackson dan Jackie Jones). Yogyakarta: Jalasutra.

Moleong, Lexy J. (2001). Metodologi Penelitian Kualitatif. Bandung: Remaja Rosdakarya.

Sugihastuti. (2000). Kritik Sastra Feminis, Teori dan Aplikasinya. Yogyakarta: Pustaka Pelajar.

Sugihastuti, dan Adib Sofia. (2003). Feminisme dan Sastra: Menguak Citra Perempuan dalam Layar Terkembang. Bandung: Katarsis.

Toer, Pamoedya Ananta. (2005). Bumi Manusia. Jakarta: Lentera Dipantara.

Wiyatmi. (2015). Kritik Sastra Indonesia Feminisme, Ekokritisme, dan New Historisme. Yogyakarta: Interlude. 